J. Perinat. Med. 16 (1988) 319

\title{
Staff escorting centralized cardiotocographic surveillance (level 3: cardiotocographic surveillance)
}

\author{
Diether W. Langnickel \\ Department of Obstetrics and Gynecology I, Central Municipal Hospital St.- \\ Juergen-Straße, Bremen, West Germany
}

The quality of surveillance of parturition depends on manpower and equipment available in a hospital. The allocation of these resources is related to the rate of deliveries, percentage of high risk pregnancies, and obstetrical management. During the last two decades the delivery rate declined. To allocate manpower, the distribution of daily deliveries was analyzed (figure 1). While in 1986 the distribution over the three shifts appears quite even, there were obviously fewer deliveries during the night shift than during the other two shifts in 1974. An analysis (figure 2) showed that the decline of the duration of labor between 1963 and 1973 was essentially caused by a more active management of labor [1]. More inductions or augmentations of labor by oxytocin, increased rates of cesarean sections, forceps and vacuum extractions. New methods of anesthesia such as epidural anesthesia may cause adverse effects. The distribution of daily deliveries changed dramatically (figure 3 ). In $197350 \%$ of the deliveries took place between $8 \mathrm{a} . \mathrm{m}$. and $4 \mathrm{p}$. m. As the hospital became a perinatal center for a larger region, the percentage of high risk pregnancies increased. In 1986, at a rate of 1,425 deliveries 80.9 per cent were high risk pregnancies and deliveries. Besides the distribution of daily deliveries, the maximum simultaneous occupancy of delivery beds representing patients in labor was analyzed. At a rate of 1,000 deliveries per year in $16 \%$ of the shifts the delivery rooms were empty (figure 4). In $35 \%$ of the shifts at least 1 patient was in labor. In $25 \%$ of the shifts at least two patients were in labor simultaneously. The simultaneous occupancy of delivery beds changes with the rate of deliveries per year. For example the maximum simultaneous occupancy of

\section{Curriculum vitae}

Dr. DiETHER W. LANGNIKKEL, F. I. A.C. was born in 1930. He graduated from the University of Heidelberg. He trained and was senior resident in the Department of Obstetrics and Gynecology, Municipal Hospital Mannheim. He was a Assistent Director, Department of Obstretrics and Gynecology, Municipal

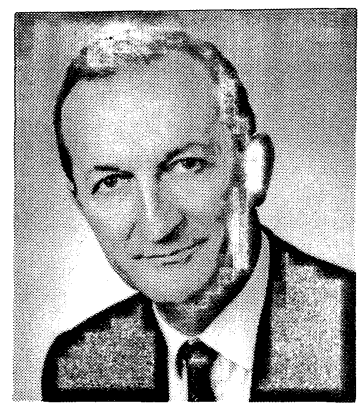

Hospital Solingen, and is a fellow of the International Academy of Cytology. From 1979-1981, he was a member of the presidium of the German Society for Perinatology. Since 1976 he is Director of the Department of Obstetrics and Gynecology I, Central Municipal Hospital St.-Juergen-Strasse, Bremen.

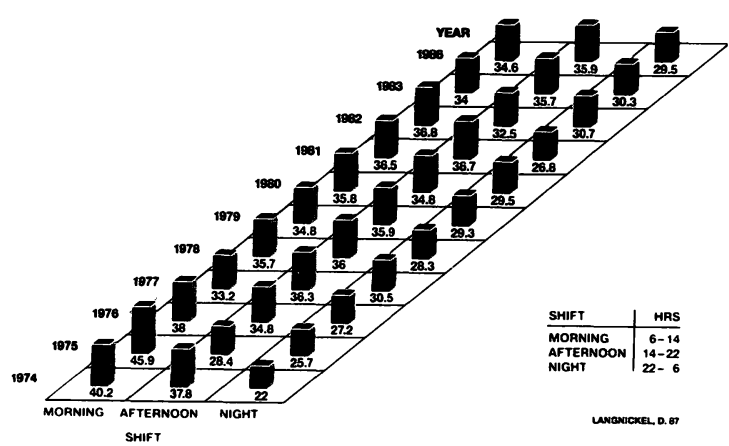

Figure 1. Deliveries per shift (per cent) at the Women's Hospital St. Juergenstrasse, Bremen 1974-1986. 

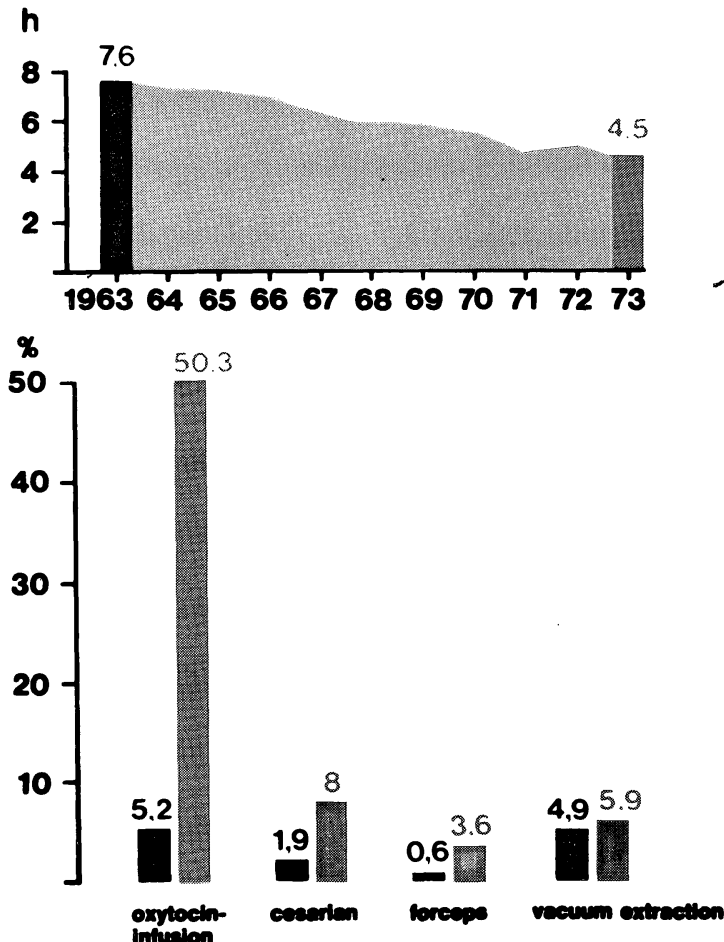

Figure 2. Influence of active management on the duration of labor.

four delivery beds per shift rises from 4.1 per cent at a rate of 1,000 deliveries per year to $12,3 \%$ at a rate of 1,900 deliveries per year (figure 5). In West Germany parturients are supervised during first stage primarily by midwives. Table I shows the minimum staff on duty in our hospital from $4 \mathrm{p} . \mathrm{m}$. to $6 \mathrm{a} . \mathrm{m}$. and on weekends. For 1,400

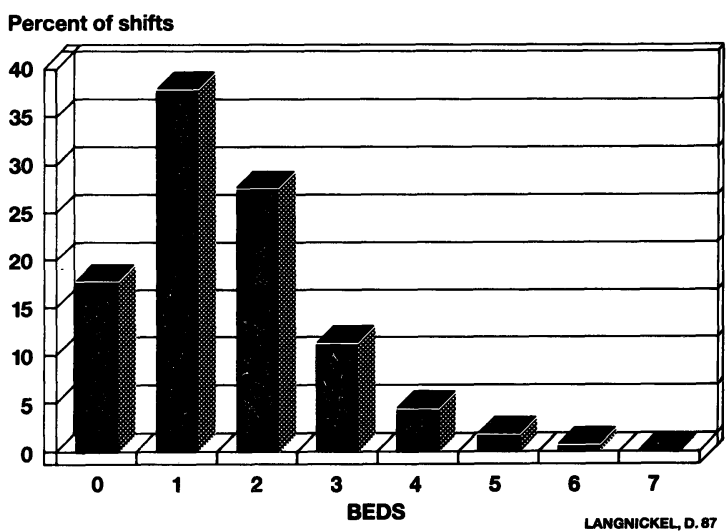

Figure 4. Maximum simultanous occupancy of delivery beds at a delivery rate of 1000 per year.

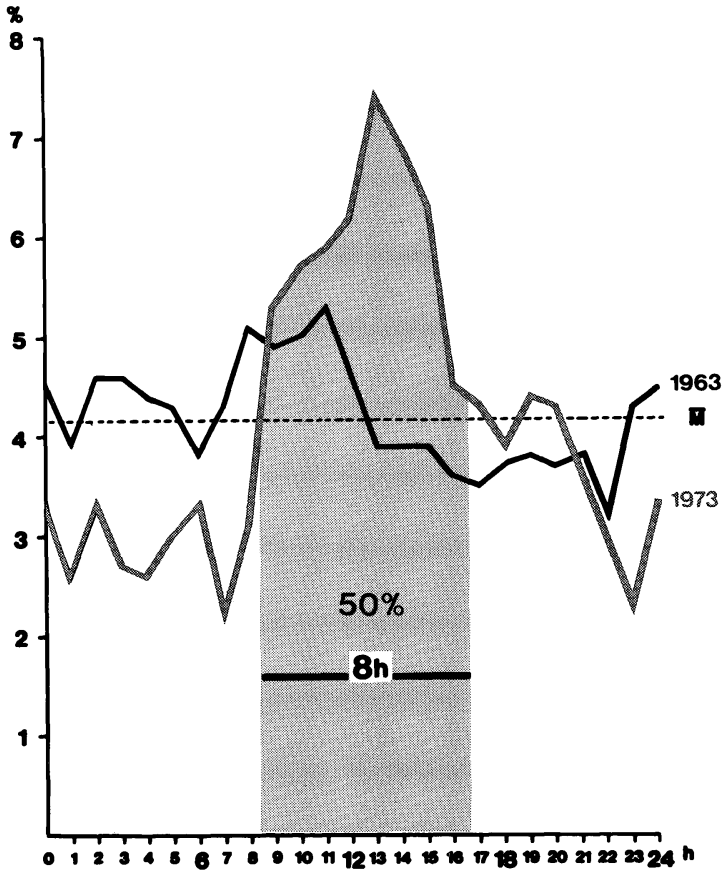

Figure 3. Influence of active management of labor on the circadian distribution of deliveries.

deliveries per year 13 midwives are employed, which is fairly good. The West German Hospital Society recommends a ratio of 1 midwife for 2 women in labor. In 1974 in over $8 \%$ of the shifts more than 4 patients were simultaneously in labor. To avoid unnoticed fetal distress, cardiotocograms from up to eight bedside monitors were transmitted to displays in a central control room, e. g. level

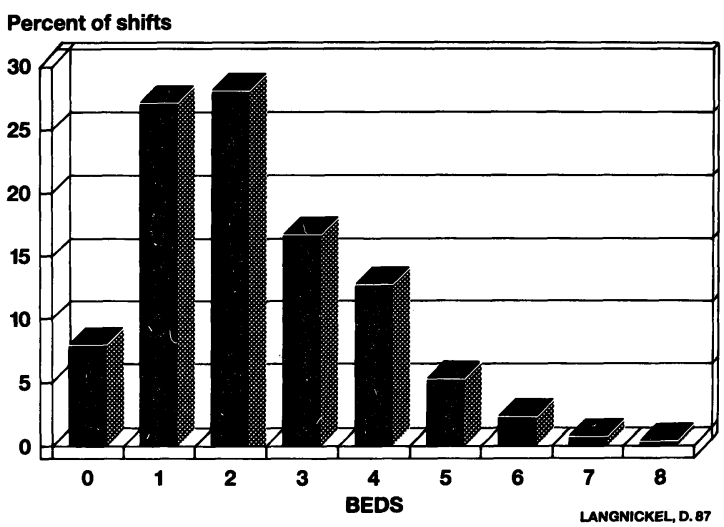

Figure 5. Maximum simultanous occupancy of delivery beds at a delivery rate of 1900 per year.

J. Perinat. Med. 16 (1988) 
Table I. Staff on duty in the Womens' Hospital St. Juergenstraße, Bremen 1986.

Staff on duty in the Women's Hospital (Minimum*)

2 Midwives**

3 Obstet. residents

1 Fulltime attending obstetrician

1 Pediat. resident

(* from 16 to $6 \mathrm{hrs}$ and on weekends)

(**) per shift)

1: bedside cardiotocography had been supplemented by level 2: centralized cardiotocographic surveillance. Each one of the eight displays was connected to an alert modul system. Flashing indicators and audio alert were activated if preprogrammed standards of baseline, deceleration area, variability, amplitude or uterine activity were exceeded. Figure 6 shows a night shift situation with one patient being delivered by a doctor and a midwife while the other six patients were supervised by the second midwife in the central control room who also took care of an incoming new patient. When she left the central control room to see patient no. 1 , the central displays were necessarily left behind and all cardiotocograms except those in room 1 and 6 could not be supervised.

\section{delivery rooms}

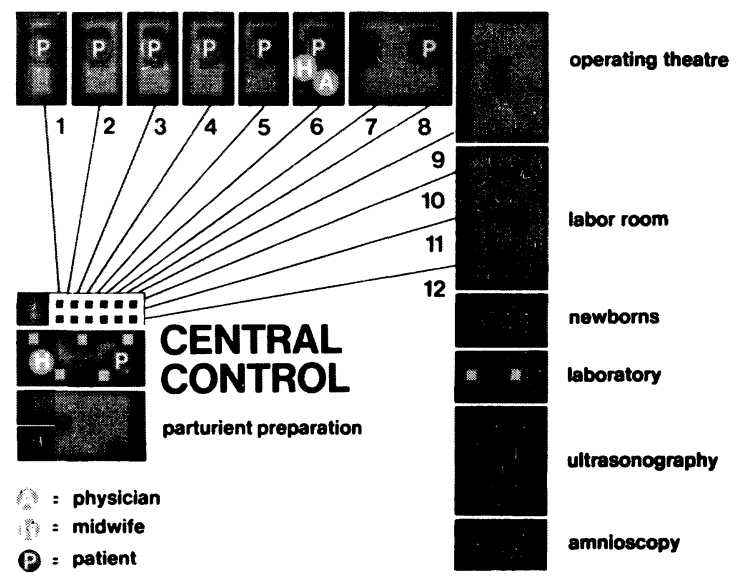

Figure 6. Centralized cardiotocographic surveillance at the Women's Hospital St. Juergenstrasse Bremen 19731985. During night shift 7 patients in labor. 1 patient being delivered by midwife and doctor, second midwife taking care of a new incoming patient and supervising central displays.
Theoretically one could ask for 7 midwives per shift, one for each patient in this situation. To have 7 midwives in each shift, 35 midwives would be needed altogether. At a rate of 1,900 deliveries per year, each midwife would do 54 deliveries per year, one per week. Such maximized manpower would be counterbalanced by minimized skills because of insufficient training. Such a staff could never be financed in West Germany. If one centralizes the data from bedside monitors in this way, there is the danger of staff members sitting in the control room instead of being at the bedside of the patients in labor. The advantage of safety is counterbalanced by the disadvantage of inhumanity.

The new womens' hospital St. Juergenstrasse in Bremen was opened in 1986. A level 3: staff escorting centralized cardiotocographic surveillance (table II) was set up (figure 7). Delivery rooms, high risk pregnancy ward, and antenatal clinic were concentrated on one floor to enhance rapid interaction and exchange of staff and equipment. The new system has a CTG-input from 6 delivery rooms - 3 standard, 3 homelike - and one operating theatre where trial forceps, vacuum extraction in double-set-up are performed 1 cardiotocography room and 1 high risk pregnancy ward room. Table III shows the central display for up to 9 patients. From the computer in the central

Table II. Level 3: Staff escorting centralized cardiotocographic surveillance

\begin{tabular}{ll}
\hline Level & Cardiotocographic surveillance \\
\hline 1 & bedside \\
2 & centralized \\
3 & staff escorting centralized \\
\hline
\end{tabular}

Table III. Staff escorting centralized cardiotocographic surveillance - input.

CTG input from:

6 Delivery rooms

3 standard

3 homelike

1 Operating theatre

1 Cardiotocography room

(1 of 3 beds)

1 High risk pregnancy ward room (1 of 2 beds)

9 Patients 


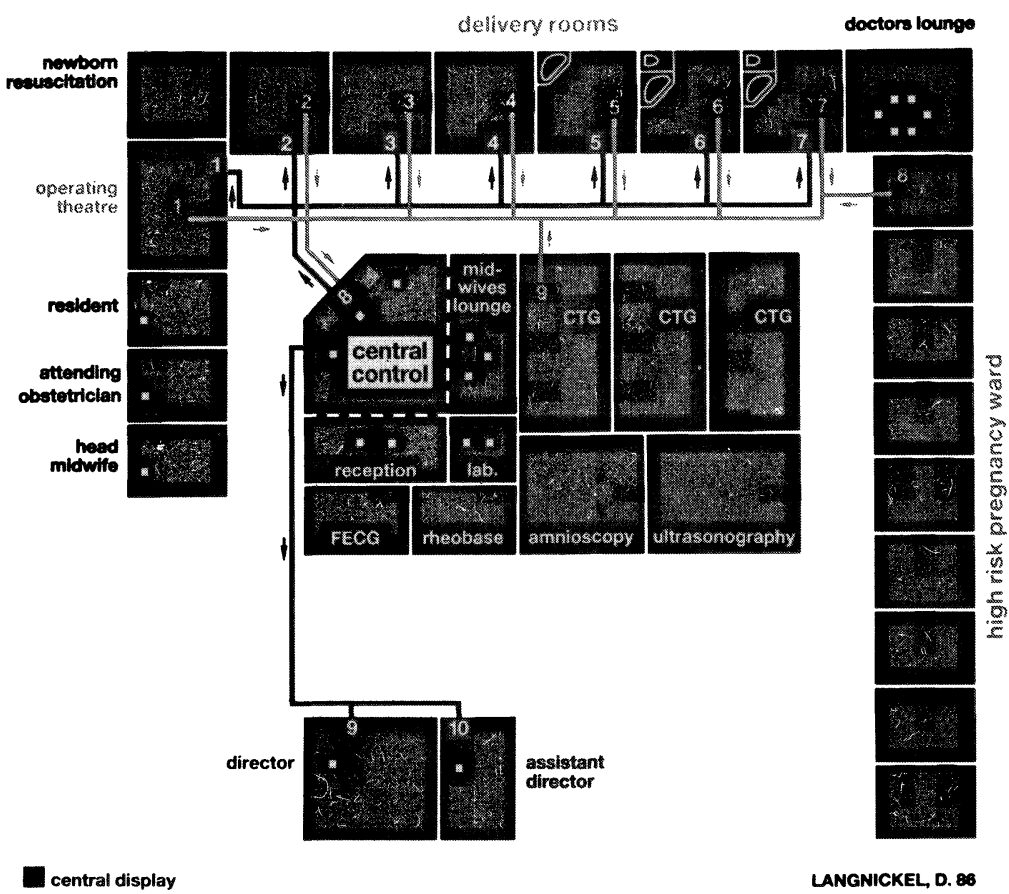

Figure 7. Staff escorting centralized cardiotocographic surveillance system in the new Womens' Hospital St. Juergenstrasse, Bremen 1986.

control room centralized data are transmitted to displays in 10 rooms, to each of the 6 delivery rooms, the operating theatre, the central control room, the director's offices (table IV). From the midwives' lounge and the reception one can watch the displays in the central control room through large windows. Figure 8 shows a central display

Table IV. Staff escorting centralized cardiotocographic surveillance - output.

Central displays in:

6 Delivery rooms

3 standard

3 homelike

1 Operating theatre

1 Central control room

+ midwives lounge

+ reception

1 Director

1 Assistant director

10 Rooms in one of the homelike delivery rooms with a kingsized bed, rocking chair and radio with tape recorder. On the other side this room has a heated table for dressing the baby, a spot light, a bathtub and a toilet. Because a remarkable percentage of parturients are interested in natural birthing, we hide technical equipment in our homelike delivery rooms. For example, the spotlight is behind a board, the central monitor behind a roller-shutter. If any of the nine cardiotocograms, that can be transmitted to the central display, exceeds preprogrammed borderline values, a green light of $4 \mathrm{~mm}$ diameter starts flashing and a buzzer sounds. Then a staff member in this room will lift the roller-shutter and see where the alert occurs. On each central display a $20 \mathrm{~min}$. cardiotocogram from up to 9 patients can be viewed simultaneously (figure 9). If the fetal heart rate in one cardiotocogram exceeds pre-programmed borderline values an inverse flashing picture of this cardiotocogram appears on the display. At present tachycardia alert starts if the baseline exceeds 160 beats per minute for more than $180 \mathrm{sec}$. and bradycardia alert starts if the baseline drops below 110 beats per minute for more than 50 seconds. 


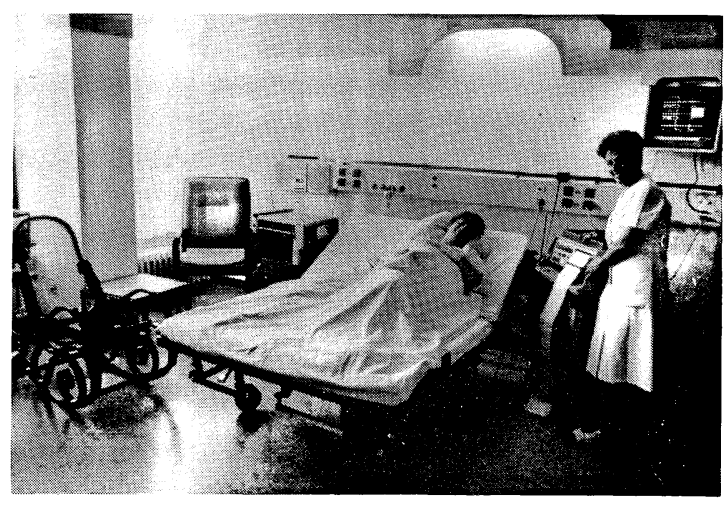

Figure 8. Homelike delivery room with central display.

This default value is valid for all nine cardiotocograms and can be changed individually for each cardiotocogram according to special situations. We asked 8 hospitals with the same obstetrical management system how they pre-programmed the default values. All 9 hospitals use tachycardia borderlines between 160 and 180 - on the average 49 seconds (table $\mathrm{V}$ ). If during labor, station and
Table V. Fetal heart rate baseline default alert. Alert limits from 9 hospitals.

Fetal heart rate baseline default alert*

\begin{tabular}{|c|c|c|}
\hline Baseline alert limits & mean & median \\
\hline $\begin{array}{l}\text { Tachycardia baseline } \\
\text { (bpm) }\end{array}$ & $168(160-180)$ & 160 \\
\hline $\begin{array}{l}\text { Tachycardia lag-time } \\
\text { (sec.) }\end{array}$ & $93 \quad(10-180)$ & 120 \\
\hline $\begin{array}{l}\text { Bradycardia baseline } \\
\text { (bpm) }\end{array}$ & $109(100-120)$ & 110 \\
\hline $\begin{array}{l}\text { Bradycardia lag-time } \\
\text { (sec.) }\end{array}$ & $49 \quad(10-120)$ & 50 \\
\hline
\end{tabular}

*Alert limits of 9 hospitals. One hospital changes lagtimes from $10 \mathrm{sec}$. during early labor to $20 \mathrm{sec}$. during late labor.

168 - beats per minute and a lagtime from 15 to 180 seconds on the average 93 seconds. For bradycardia they use a borderline between 100 and 120 - on the average 109 beats per minute, and a lagtime from 15 to 120 seconds - on the average

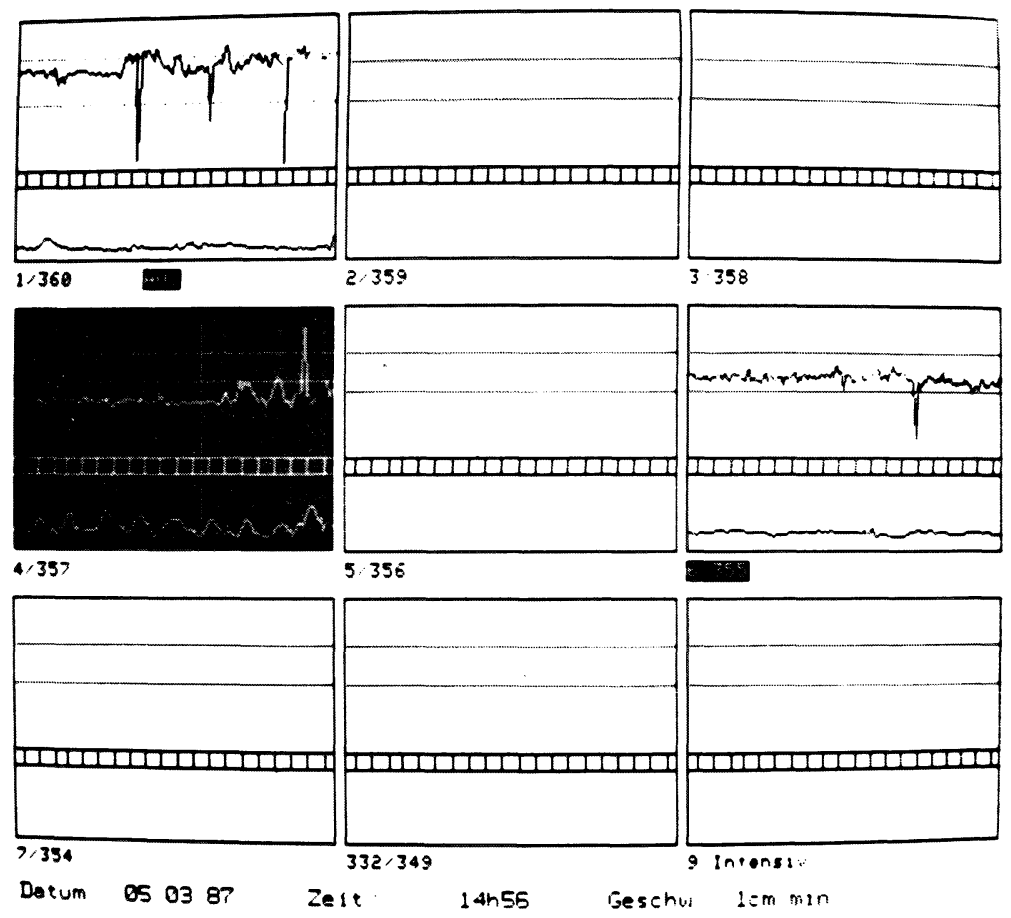

Figure 9. Central display for $20 \mathrm{~min}$. cardiotocograms of up to 9 patients. Bradycardia alert in delivery room 4 . Pelvic examination data missing for more than 2 hours in room 6. 
dilation has not been checked within two hours, another alert signal appears. The number of the bed appears inverse flashing. In the central control and in the director's office on a separate monitor the occupancy of all delivery beds is displayed showing the names of patient and midwife, parity, gravidity, estimated date of confinement, station, dilation and name of the doctor. A cardiotocogram of special interest can be magnified (figure 10). In a line between cardiotachygram and tocogram the result of the last pelvic examination (station $+3 /$ dilation $12 \mathrm{~cm}$ ) and the duration of labor (min.) are displayed. The displays in the offices of the director and the assistant director enable them to supervise and to bring in their expertise in acute alert situations instead of arguing during the staff meeting next morning when the difficult cases from the past 24 hours are reported. While the central display in the director's office shows the cardiotocograms of up to 9 patients or the magnification of one of them, on a second monitor the patient's data or the partogram can be shown. Figure 11 shows WeSTIN's partogram of a primipara. The borderlines of the triangle show the longest and shortest duration of labor to be expected, calculated from a certain
Table VI. Requirements for humane and safe parturition.

Human and safe parturition

No parturient should be alone during labor.

Fulltime attending obstetrician should be present 24 hours in the hospital.

No cardiotocogram should exceed alert borderline-values unnoticed.

station and dilatation at the beginning of labor [2]. The individual progress is shown by X-es. In this case there is a steady state at a station of -4 and a dilatation of $4 \mathrm{~cm}$ for quite a while due to insufficient uterine contractions. After augmentation by oxytocin, labor progressed and the results of further pelvic examinations were within the normal range. With each pelvic examination, molding, length of the cervical canal and strength of contractions are noted. On the same display the results of examinations at different times and other events are also shown. The whole system is run by a software that can always be changed and adapted to the actual state of knowledge in obstetrics.

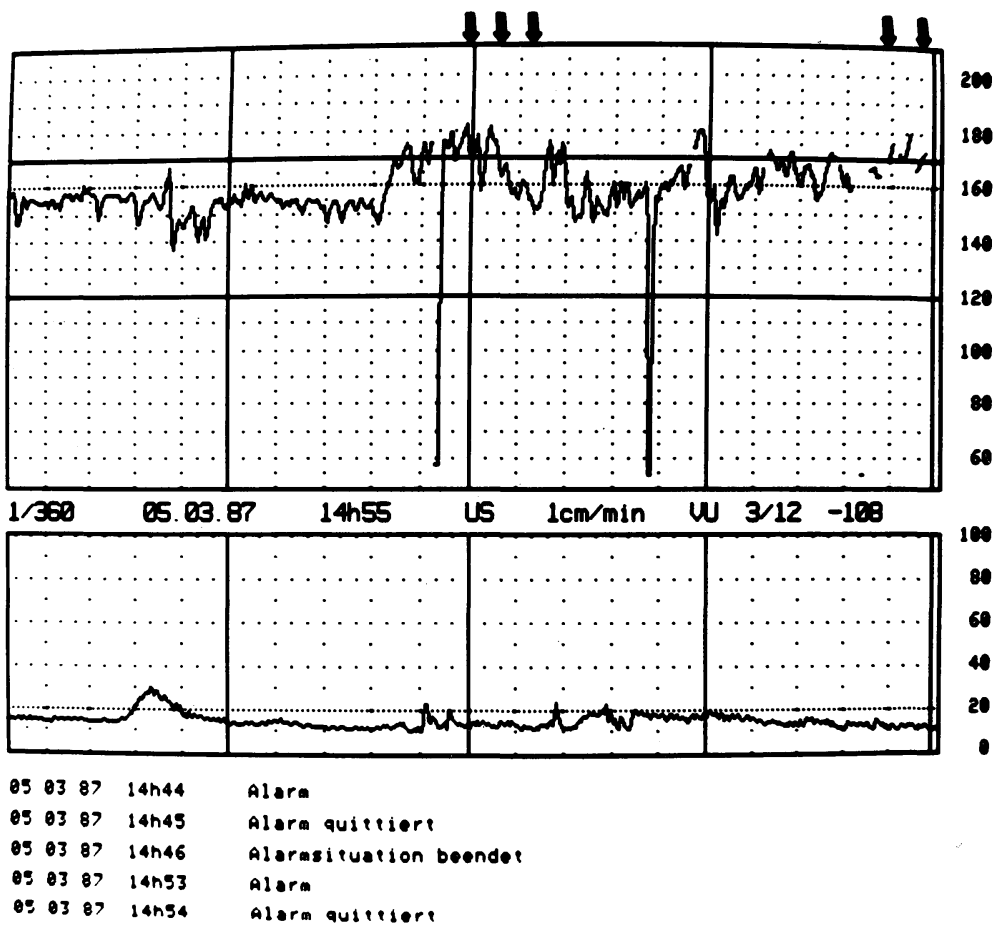

Figure 10. Magnified $20 \mathrm{~min}$. cardiotocogram on central display. 


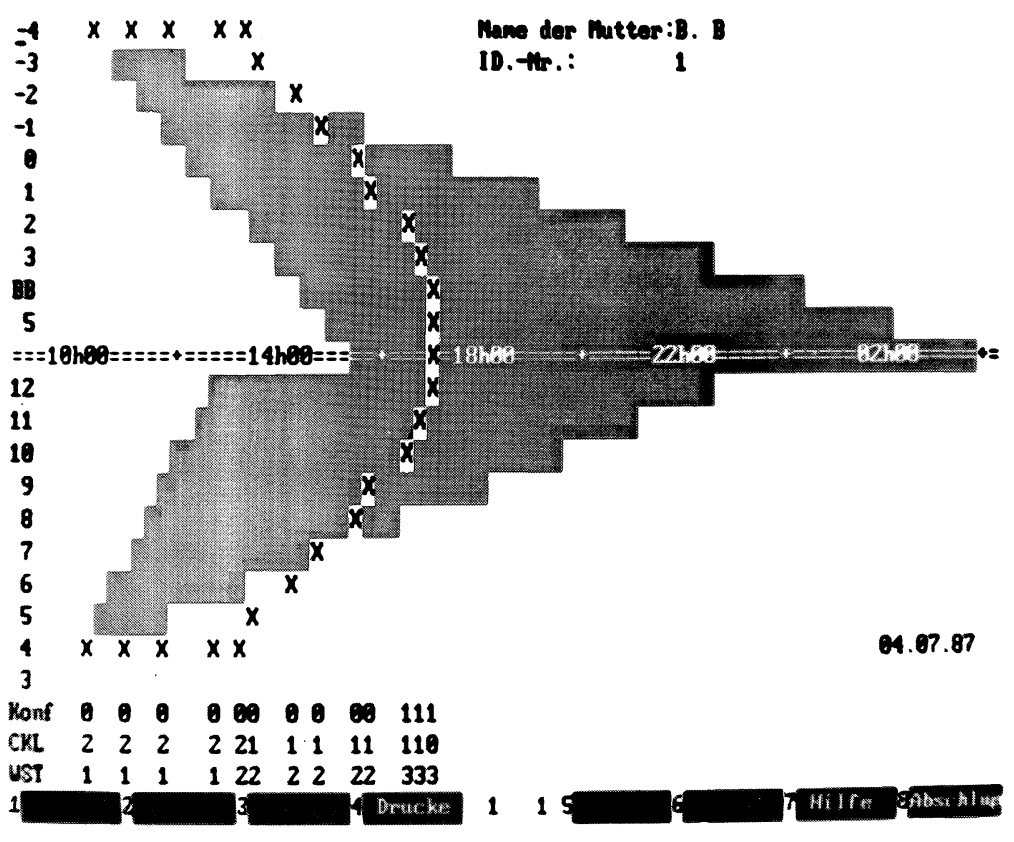

Figure 11. Partogram of primipara. Acceleration of slow labor by oxytocin.

To achieve a humane and safe parturition (table VI) no mother should be alone during labor. With the exception of hospitals with midwivery schools where midwife students accompany parturients, in the Federal Republic of Germany this can only be achieved at the $100 \%$ level if the husband or another relative or friend are engaged, because of the limited manpower mentioned above. A full time attending obstetrician must be present 24 hours in the hospital. To make sure that no cardiotocogram exceeds borderline values unnoticed, staff escorting of centralized cardiotocographic surveillance is necessary.

\begin{abstract}
As cardiotocograms may exceed borderline values unnoticed if the parturient/staff ratio exceeds $1 / 1$ the distributions of deliveries and simultaneous occupancies of delivery beds over 11 years are analyzed. Variable influences, for example the management of labor, are out-
\end{abstract}

lined. The first level 3: staff escorting of centralized cardiotocographic surveillance in a family oriented obstetrical set up and its computerbased alert-system are described. Requirements for humane and safe parturition are formulated.

Keywords: Cardiotocography; cardiotocography, borderline-alert; cardiotocography, centralized; cardiotocography, staff escorting surveillance; cardiotocography, surveillance; manpower, obstetrics; organizatory risk in obstetrics; parturition, circadian distribution; parturition, surveillance.

\section{Zusammenfassung}

Mitarbeiter begleitende zentralisierte kardiotokographische Überwachung (Stufe 3: Kardiotokographische Überwachung)

Um die zur Geburtsüberwachung erforderlichen Mitarbeiter und Geräte festzulegen, wurde die zirkadiane Verteilung von Geburten und die gleichzeitige Belegung von
Gebärbetten über 11 Jahre analysiert. Der Einfluß der Geburtsleitung auf die zirkadiane Verteilung der Geburten wird dargelegt. Der Prozentsatz von Schichten, in denen ein empfohlenes Verhältnis von $2 / 1$ Gebärenden zu Hebammen überschritten wird, wurde bei unterschiedlichen jährlichen Geburtenraten analysiert. Stufe 
1 (bettseitige Kardiotokographie) und Stufe 2 (zentralisierte kardiotokographische Überwachung) der kardiotokographischen Überwachung beinhalten das Risiko, $\mathrm{da} ß$ unerkannte fetale Gefahrenzustände mit einer $\mathrm{Ku}$ mulation gleichzeitig laufender Geburten zunehmen. Aus diesem Grund ist es erforderlich mittels Stufe 3: „Mitarbeiter begleitende zentralisierte kardiotokographische Überwachung" die Kontrollfähigkeit des Per- sonals durch moderne Technologie zu erweitern. Das erste System dieser Art wurde in der Frauenklinik des Zentralkrankenhauses St. Jürgenstraße, Bremen, im Februar 1986 eingerichtet und wird beschrieben. Grenzwert Alarme, wie sie mittlerweile in 9 Krankenhäusern für baseline-Alarm Verwendung finden, werden dargestellt. Anforderungen an eine humane und sichere Geburt werden formuliert.

Schlüsselwörter: Geburten, gleichzeitig ablaufende; Geburten, zirkadiane Verteilung; Geburtsüberwachung; Kardiotokographie; Kardiotokographie, Grenzwert-Alarm; Kardiotokographie, Mitarbeiter begleitende Überwachung; Kardiotokographie, zentralisierte; Kardiotokographie, Überwachung; Mitarbeiter, Geburtshilfe; Organisatorisches Risiko in der Geburtshilfe.

\section{Résumé}

Surveillance cardiotocographique centralisée accompagnant par le personel (Degré 3: surveillance cardiotocographique)

On a analysé sur 11 ans la distribution circadienne des accouchements et l'occupation simultanée des lits d'accouchements afin de déterminer les besoins en hommes et les équipements nécessaires. On a décrit l'influence de la prise en charge du travail sur la distribution circadienne des accouchements. Pour différents taux de naissances annuels, on a analysé le pourcentage de roulements lorsque le ratio des parturientes sages femmes a depassé $2 / 1$. Le degré 1 (cardiotocographie à côté du lit) et le degré 2 (surveillance cardiotocographique centra- lisée) impliquent un risque de souffrance fæatale non diagnostiquée qui croît avec l'augmentation des accouchements.

C'est pourquoi le degré 3 ou surveillance cardiotocographique centralisée accompagnant le personnel devient nécessaire pour compenser le manque de personnel par la technologie en place dans le département d'obstétrique et de gynécologie de l'hôpital municipal central St. Juergen-Strasse, à Brême, RFA, en février 1986. Il est décrit dans cet article. Les valeurs des alertes utilisées dans 9 hôpitaux sont présentées. On formule les conditions nécessaires pour un accouchement humain at en sécurité.

Mots-clés: Accouchement simultané; cardiotocographie; cardiotocographie centralisée; distribution circadienne de l'accouchement; organisation impropre en obstétrique; surveillance cardiotocographique centralisée accompagnant le personnel; surveillance de l'accouchement.

\section{References}

[1] LANGNICKEL D: Geburtshilfliche Intensivüberwachung in einem kommunalen Zentralkrankenhaus. Deutsches Ärzteblatt 72 (1975) 2049
[2] Westin B: Aktiv förlossningsledning medels partogram. Symposium Ann Meeting Swed Gyn Soc 1963, Nord Med 72 (1964) 913

Dr. Diether Langnickel, F. I. A. C.

Director of the Department of

Obstetrics \& Gynecology I

Zentralkrankenhaus St.-Juergen-Straße

D-2800 Bremen 1, West Germany 